Acta vet. scand. 1986, 27, 397-409.

From the National Veterinary Institute, and the Department of Internal Medicine I, Division of Parasitology, Norwegian College of Veterinary Medicine, Oslo, Norway.

\title{
THE PREVALENCE OF ELAPHOSTRONGYLUS CERVI INFECTION IN MOOSE (Alces alces) IN SOUTHERN NORWAY
}

\author{
By \\ Gudbrand Stuve
}

\begin{abstract}
STUVE, G.: The prevalence of Elaphostrongylus cervi infection in moose (Alces alces) in Southern Norway. Acta vet. scand. 1986, 27, 397-409. - The prevalence of Elaphostrongylus cervi infection in moose shot during the hunting season 1983 in 47 different municipalities in Southern Norway was studied. E. cervi seemed to occur endemically in the population, as infection was found in $35 \%$ of 1,982 moose examined. Diagnosis was made on the basis of the presence of eggs and first-stage larvae $\left(L_{1}\right)$ and associated histopathological lesions in the lung, and on the presence of $L_{1}$ in the faeces. The prevalence varied considerably between different municipalities. No relationship was found between the prevalence of $E$. cervi and the population density of moose. The highest prevalence was found in municipalities where red deer harbouring $E$. cervi were also present. The prevalence among males was higher than among females, and that among yearlings higher than among calves and adults. In no case was infection found in animals $5 \frac{1}{2}$ years of age or older. Carcass weight in infected adult moose was significantly lower than in non-infected adults.
\end{abstract}

elaphostrongylidae; cervidae; epidemiology; geographical distribution; general condition.

Protostrongylid nematodes in the genus Elaphostrongylus occur in a variety of cervids. However, little is known about the occurrence and significance of these worms in moose (Alces alces). Nilsson (1971) listed Elaphostrongylus sp. as a parasite occurring in Swedish moose, whereas from Russia Pryadko \& Boev (1971) mentioned moose as host for E. panticola Lubimow 1945. From Canada Lankester (1977) described an experimental infection with E. cervi Cameron 1931, in a moose calf. Holt (1982) reported that infection with Elaphostrongylus sp. was 
the probable cause of increased mortality among moose, especially calves, in some areas in Norway.

The taxonomy of the genus Elaphostrongylus has not yet been settled. The 3 species described: E. cervi Cameron 1931, E. panticola Lubimow 1945, and E. rangiferi Mitskevich 1958 are regarded by most authors as representing a single species. Consequently, the species names E. panticola and E. rangiferi are considered to be synonyms for E. cervi (Pryadko \& Boev 1971, Kutzer \& Prosl 1975, Pryadko 1976, Lankester \& Northcott 1979). Other workers, however, consider them to be 3 separate species (Halvorsen pers. com.). In the present paper the species found in moose will be referred to as E. cervi.

The present study reports the prevalence of $E$. cervi infection in moose in Southern Norway. Besides describing geographical differences, the present paper evaluates findings concerning the relationship between the prevalence of $E$. cervi infection in moose on the one hand, and the population density, age and sex of moose, and the occurrence of other cervids harbouring elaphostrongylid nematodes on the other. The paper also describes the effect of E. cervi infection on general body condition, assessed according to differences in carcass weight between infected and non-infected moose.

\section{Materials}

\section{MATERIALS AND METHODS}

Material was collected from a total of 1,982 moose shot during the hunting season in 1983 (September 25th to October 26th). The moose originated from 47 municipalities distributed throughout 13 different counties in South-Norway (Fig. 1) and represented $8.2 \%$ of all moose shot in Norway that year (Øien 1984). The municipalities represented areas with different population densities of moose and included not only areas in which moose was the only cervid present, but also areas in which moose were found together with either red deer (Cervus elaphus) or reindeer (Rangifer tarandus).

Material was collected from male and female moose of different ages in approximate accordance with the distribution of these age groups among all animals shot. It was the intention that $10 \%$ of the animals shot in each county should be represented (Table 1). The animals from which samples were collect- 


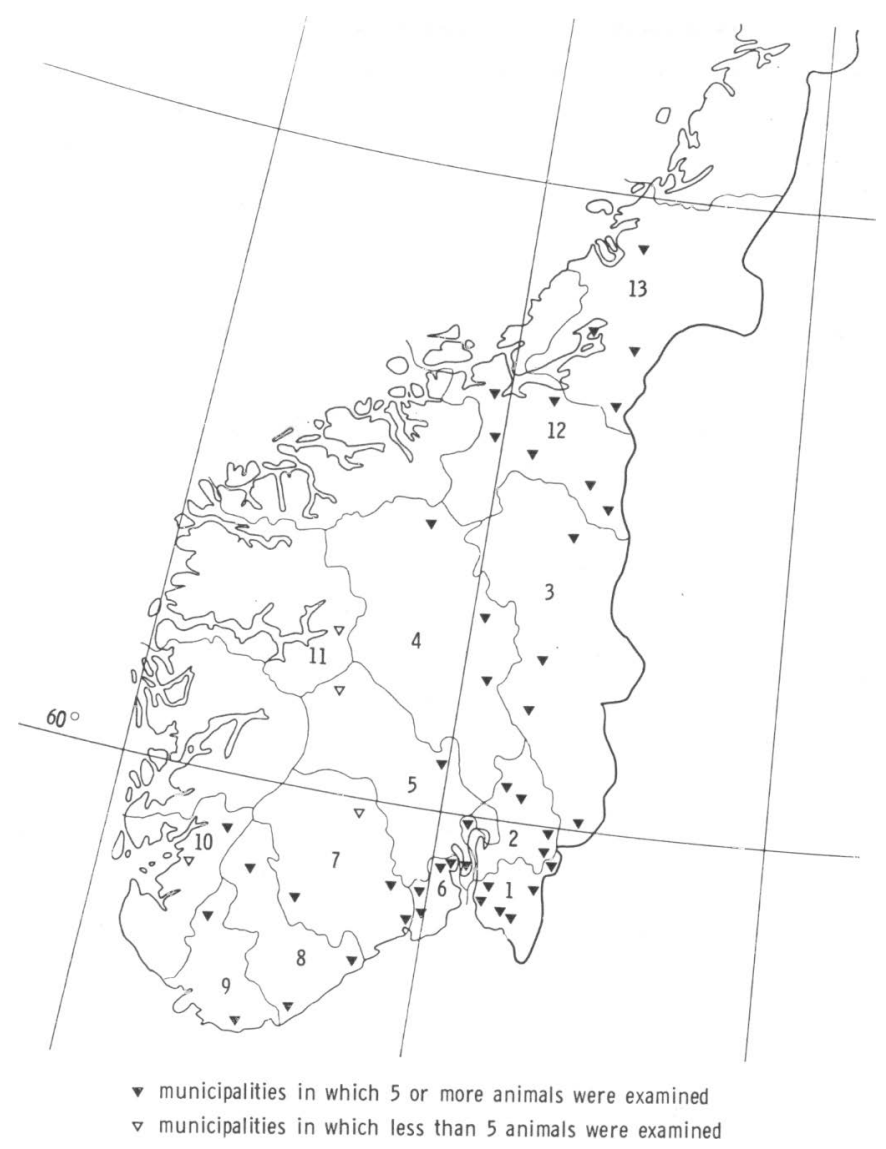

Figure 1. The location of the municipalities and counties (Ref. Table 1) in Southern Norway included in the study.

ed, were stratified according to sex and age. Each of these groups were assumed to be randomized by the chance of the animals being shot.

The hunters were asked to record sex, age, carcass weight, general condition and observations of any signs of neurological disorders in the animals concerned. They were also asked to report the occurrence of red deer or reindeer on their hunting grounds.

The caudal half of 1 diaphragmatic lobe of the lung and 20 cm of the posterior part of colon or rectum with faeces were collected from each animal. In addition the premolar teeth of 1 mandible from each of 269 yearlings and adults were collected. 
The ages of these animals were determined by examination of annuli in tooth cementum (Reimers \& Nordby 1968). The age of the other animals was estimated by the hunters. The material was stored at $-20^{\circ} \mathrm{C}$ from the day of slaughter until examination.

\section{Lung examinations}

A gross examination of the lungs was made for the presence of pathological changes and specific lung nematodes. Smears of bronchial mucus on microscopical slides were examined with a dissecting microscope and an ordinary light microscope for the presence of first-stage larvae $\left(L_{1}\right)$ of $E$. cervi and other nematodes. Portions of the lung were examined for $\mathrm{L}_{1}$ according to a modified Baermann-technique. Briefly, lung tissue was cut into small pieces $\left(1-3 \mathrm{~cm}^{3}\right)$ which were placed on a metal strainer in a plastic funnel, to which $500 \mathrm{ml}$ of tap water was added. After 17-18 $\mathrm{h}$ the sediment was examined for the presence of larvae. For histological examination portions of the lung (tissue with a normal appearance and tissue showing gross changes) were fixed in $10 \%$ Formol and processed in the normal manner. Paraffin-embedded sections were stained with haematoxylin and eosin (HE) and examined for nematode eggs, $\mathrm{L}_{1}$ and histopathological lesions.

\section{Faecal examinations}

Ten grams of faeces were subjected to baermannisation in plastic funnels with $75 \mathrm{ml}$ of tap water for $17-18 \mathrm{~h}$. The sediment was transferred to test-tubes and water added to a final volume of $10 \mathrm{ml}$. The contents were mixed and $1 \mathrm{ml}$ pipetted onto a glass slide for microscopical counting of $L_{1}$, the larval count thus representing the number of larvae per gram of faeces (LPG). If no $L_{1}$ were found, the remaining $9 \mathrm{ml}$ of suspension were centrifugated at $2,500 \mathrm{rpm}$ for $5 \mathrm{~min}$ and the sediment examined for $L_{1}$. No specific $L_{1}$ count was carried out in this respect, but when larvae were present, the LPG of the animal concerned was for practical reasons expressed as 1 .

\section{Statistics}

Chi-square test, F-test and correlation were used for statistical calculations. $P$ values of $<0.01$ were considered significant. 


\section{RESULTS}

Examination of lungs and faecal samples revealed that 692 (35\%) of the 1,982 moose examined were infected with E. cervi. Table 1 presents the prevalence of $E$. cervi infection in moose in each of the counties included in the study. There was considerable variation in the prevalence of $E$. cervi infection between different municipalities, even between neighbouring municipalities within the same county such as Holtålen (42\%) and Røros (6\%) in S $\phi r-T r \phi n d e l a g$ or Nannestad (40\%) and Ullensaker $(26 \%)$ in Akershus.

Table 1. The prevalence of $E$. cervi infection in moose in 13 counties in Southern Norway as detected by examination of lungs and faeces.

\begin{tabular}{lrcr}
\hline County & $\begin{array}{c}\text { No. of } \\
\text { animals }\end{array}$ & $\begin{array}{c}\text { Preval- } \\
\text { ence \% }\end{array}$ & $\begin{array}{c}\text { Animals examined as } \\
\text { the \% of all animals } \\
\text { shot in the county }\end{array}$ \\
\hline 1. Østfold & 202 & 39 & 11 \\
2. Akershus & 207 & 37 & 14 \\
3. Hedmark & 488 & 39 & 7 \\
4. Oppland & 213 & 35 & 11 \\
5. Buskerud & 80 & 34 & 6 \\
6. Vestfold & 108 & 25 & 13 \\
7. Telemark & 108 & 25 & 6 \\
8. Aust-Agder & 146 & 27 & 10 \\
9. Vest-Agder & 95 & 19 & 9 \\
10. Rogaland & 7 & 43 & 18 \\
11. Sogn og Fjordane & 1 & 0 & 13 \\
12. Sør-Trøndelag & 157 & 41 & 7 \\
13. Nord-Tr $\varnothing$ ndelag & 170 & 42 & 9 \\
\hline Southern Norway & 1,982 & 35 & \\
\hline
\end{tabular}

Of the methods used histological examination was positive in 676 cases, baermannisation of the lung in 639, baermannisation of faeces also in 639, and direct examination of bronchial mucus in 468 animals. None of the animals examined had been reported as having shown signs of neurological disorder.

The mean faecal larval output of $E$. cervi in infected moose was $42 \mathrm{LPG}(\mathrm{SD}=105$ ). The highest count of 1,415 LPG was found in a $4 \frac{1}{2}$ years old bull (carcass weight $=235 \mathrm{~kg}$ ). Except for 1 male calf with 1,215 LPG, all animals with counts higher than 500 LPG were adult males. The mean faecal count in calves 
was $39 \mathrm{LPG}(\mathrm{SD}=136)$ and in yearlings $33 \mathrm{LPG}(\mathrm{SD}=57)$, while adults had 53 LPG ( $S D=137)$. The mean count of males was $51 \mathrm{LPG}(\mathrm{SD}=125)$ and that of females $20 \mathrm{LPG}(\mathrm{SD}=36)$.

Tables 2 and 3 show the prevalence of infection according to sex and age. Irrespective of the age males had higher prevalence than females whereas the prevalence declined with increasing age independent of the sex.

Table 2. The prevalence of $E$. cervi infection in male and female moose according to age.

\begin{tabular}{ccccccccc}
\hline & \multicolumn{2}{c}{ Males } & & \multicolumn{2}{c}{ Females } & & \multicolumn{2}{c}{ Total } \\
\cline { 2 - 3 } Age (years) & $\begin{array}{c}\text { No. of } \\
\text { animals }\end{array}$ & $\begin{array}{c}\text { Preval- } \\
\text { ence } \%\end{array}$ & & $\begin{array}{c}\text { No. of } \\
\text { animals }\end{array}$ & $\begin{array}{c}\text { Preval- } \\
\text { ence \% }\end{array}$ & & $\begin{array}{c}\text { No. of } \\
\text { animals }\end{array}$ & $\begin{array}{c}\text { Preval- } \\
\text { ence \% }\end{array}$ \\
\hline $1 / 2$ & 170 & 34 & & 132 & 27 & & 302 & 31 \\
$11 / 2$ & 304 & 72 & & 185 & 60 & & 489 & 671 \\
$>21 / 2$ & 665 & 27 & & 396 & 12 & & 1,061 & 21 \\
\hline Total & 1,139 & $40^{2}$ & & 713 & 27 & & 1,852 & 35 \\
Sex or age not recorded & & & & & & 130 & 34 \\
\hline
\end{tabular}

1 Significantly higher than in calves and adults $(P<0.01)$

2 Significantly higher than in females $(P<0.01)$

Table 3 . The prevalence of $E$. cervi infection in adult $\left(>2 \frac{1}{2}\right.$ years) male and female moose of known exact age (included in Table 2).

\begin{tabular}{|c|c|c|c|c|c|c|}
\hline \multirow[b]{2}{*}{ Age (years) } & \multicolumn{2}{|c|}{ Males } & \multicolumn{2}{|c|}{ Females } & \multicolumn{2}{|c|}{ Total } \\
\hline & $\begin{array}{c}\text { No. of } \\
\text { animals }\end{array}$ & $\begin{array}{r}\text { Preval- } \\
\text { ence \% }\end{array}$ & $\begin{array}{c}\text { No. of } \\
\text { animals }\end{array}$ & $\begin{array}{l}\text { Preval- } \\
\text { ence \% }\end{array}$ & $\begin{array}{c}\text { No. of } \\
\text { animals }\end{array}$ & $\begin{array}{l}\text { Preval- } \\
\text { ence \% }\end{array}$ \\
\hline $21 / 2$ & 51 & 29 & 22 & 23 & 73 & 27 \\
\hline $31 / 2$ & 24 & 20 & 8 & 13 & 32 & 19 \\
\hline $41 / 2$ & 14 & 29 & 8 & 0 & 22 & 18 \\
\hline $51 / 2-191 / 2$ & 21 & 0 & 14 & 0 & 35 & 0 \\
\hline Total & 110 & 22 & 52 & 12 & 162 & 19 \\
\hline
\end{tabular}

Table 4 shows the mean carcass weight of infected and noninfected moose. In adult $\left(>2 \frac{1}{2}\right.$ years) males the mean carcass weight of infected animals was $23 \mathrm{~kg}$ lower than in non-infected $(P<0.01)$, while in infected adult females the mean carcass weight was $17 \mathrm{~kg}$ lower than that in non-infected animals $(P<0.01)$. Among yearlings $\left(1 \frac{1}{2}\right.$ years $)$, the carcass weight of infected male and females was 6 and $4 \mathrm{~kg}$ lower than that of the corresponding uninfected animals $(P>0.01)$. 
T a b l e 4. Mean carcass weight in moose with and without E. cervi infection.

\begin{tabular}{cccccccc}
\hline \multirow{2}{*}{ Age (years) } & \multicolumn{3}{c}{ Infected } & & \multicolumn{3}{c}{ Non-infected } \\
\cline { 2 - 3 } \cline { 6 - 7 } & $\begin{array}{c}\text { No. of } \\
\text { animals }\end{array}$ & $\begin{array}{c}\text { Mean } \\
\text { weight } \\
(\mathrm{kg})\end{array}$ & SD & & $\begin{array}{c}\text { No. of } \\
\text { animals }\end{array}$ & $\begin{array}{c}\text { Mean } \\
\text { weight } \\
(\mathrm{kg})\end{array}$ & SD \\
\hline $1 / 2$ & 109 & 66.6 & 11.2 & & 235 & 66.4 & 12.2 \\
$11 / 2$ & 323 & 138.1 & 18.2 & & 155 & 143.2 & 19.2 \\
$>21 / 2$ & 227 & $189.2^{1}$ & 33.9 & & 820 & 203.5 & 36.0 \\
\hline
\end{tabular}

1 Significantly lower than in the non-infected adults $(P<0.01)$.

No relation was found between the prevalence of $\mathrm{E}$. cervi infection and the population density of moose neither for municipalities $(r=0.06)$ nor counties $(r=-0.02)$. The population densities employed were those estimated by Øien (1982) on the basis of the average number of moose shot per 10 square kilometers of forest and bogs.

The prevalence of $E$. cervi infection in moose from municipalities where no other cervids occurred, did not differ significantly $(P<0.1)$ from that in municipalities in which moose were found together with either red deer or reindeer. However, in both S $\phi$ r- and Nord-Trøndelag, where a high prevalence of E. cervi infection in moose was found (Table 1), there were a considerable number of red deer.

The lungworm Varestrongylus alces Demidova \& Naumytsjeva 1954 was found in 157 moose $(8 \%), 42$ animals being infected with both V. alces and E. cervi. The diagnosis of V.alces was made on the basis of the presence of typical situated bronchopneumonia and brood nodules containing eggs and $L_{1}$. From 43 of the animals adult V. alces were isolated from brood nodules. Lungworms recognized as Dictyocaulus sp. were found in the lungs of 13 moose, and in 7 of these animals they were present together with E. cervi. The diagnosis of Dictyocaulus sp. was made on the basis of the demonstration of adult nematodes or $\mathrm{L}_{1}$ in bronchiae and bronchioli.

\section{DISCUSSION}

The present investigation clearly shows that E. cervi is present in moose throughout Southern Norway. The moose seems to be a natural host, the wide distribution and high prevalence of E. cervi infection indicating that this host/parasite relation- 
ship is well established. Moreover, the high prevalence among yearlings estimated in the present study indicates that a large proportion of the moose population become infected with E. cervi.

E. cervi appears to have a negative influence on the general condition of infected moose, the difference in carcass weight between infected and non-infected animals increasing with age. Some of the yearlings infected as calves during the previous summer might have died of elaphostrongylosis during the winter. The actual negative effect of $\mathbf{E}$. cervi might therefore be greater than revealed in the present study.

The Norwegian moose population has shown a steady increase over the last 50 years (Reimers 1981). This together with the high prevalence of $E$. cervi infection revealed in the present study indicates that the parasite is not particularly pathogenic to moose. Though improved game management and the disappearance of natural predators have contributed to population growth and might have obscured a possible negative influence of E. cervi on the population, mortality due to E. cervi infection in moose is nevertheless probably low.

The estimated prevalence of $E$. cervi infection might be somewhat lower than the true prevalence in the population. The marked difference in the prevalence between yearlings and adults (Table 2) suggests that the animals develop immunity against this parasite. An acquired immunity might reduce the fecundity or cause expulsion of established worms and prevent establishment of new ones. Appropriate serological methods would probably have shown a somewhat higher infection rate. In reindeer Gaudernack et al. (1984) have shown that $\mathrm{L}_{1}$ of $\mathrm{E}$. rangiferi are capable of eliciting an immune response, resulting in reduced larval shedding. In the present study a similar effect is indicated by the decrease in faecal larval counts with increasing age and the absence of larvae from animals which were $5 \frac{1}{2}$ years of age or older.

Lankester (1977) found the prepatence of $E$. cervi in moose to be 64 days, whereas the prepatence of $E$. rangiferi in reindeer by Mitskewich (1964) is suggested to be $2-4$ months. In the present study diagnosis was based on the demonstration of eggs and larvae. Some animals which proved to be negative for $E$. cervi eggs and larvae, might nevertheless have been harbouring an $E$. cervi infection in the prepatent period.

Different terrestrial or aquatic Gastropods are required as 
intermediate host for the development of infective third-stage larvae $\left(\mathrm{L}_{3}\right)$ of elaphostrongylid nematodes. Due to winter climatic conditions in Norway, and thus the availability of Gastropods, infection of moose with $\mathrm{E}$. cervi is only possible between May and November. Due to the temperature dependent development of the $\mathrm{L}_{3}$ (Halvorsen \& Skorping 1982), the number of snails with infective larvae will probably increase during the summer. Accordingly the chance of moose becoming infested will increase. Moreover, the faecal larval output is probably at a minimum in summer and autumn. This has been shown in both red deer (Prosl \& Kutzer 1980) and reindeer (Wissler \& Halvorsen 1976). In the light of these circumstances and the long prepatence period it would probably have been better to have collected material in late winter. However, for practical reasons, the hunting season is the only possible time of the year in which to obtain material from a significant number of moose.

In moose from the 2 nothernmost Norwegian counties, Troms and Finnmark, Halvorsen \& Wissler (1983) found protostrongylid $\mathrm{L}_{1}$, assumed to be larvae of an Elaphostrongylus sp., in the feacal samples from $32 \%$ and $10 \%$ of the animals examined respectively. Both prevalence of infection and magnitude of the faecal larval output corresponds well with the results presented here. Moreover, E. cervi seems to be endemic in the entire Norwegian moose population.

Stress associated with rutting may be responsible for some of the differences shown in both prevalence of infection and larval counts between males and females. This has been demonstrated in both red deer and reindeer (Ottestad 1983). The difference in prevalence between male and female calves (Table 2) can not relate on breeding activities but might indicate that males in general are more susceptible to this infection than females.

Histological examination of the lungs proved to be the most reliable method for detection of an $E$. cervi infection employed in the present study. Eggs of E. cervi are transported via Arteria pulmonalis to the lungs (Prosl \& Kutzer 1980). In this manner they are disseminated to all parts, in contrast to specific lung nematodes, which have a predilection for certain sites in the lung. Moreover, the well scattered eggs and $\mathrm{L}_{1}$ causes typical histopathological changes throughout the lungs (Munro \& Hunter 1983). 
The first-stage larvae of $\mathrm{V}$. alces are difficult to differentiate from those of $E$. cervi. However, such differentiation can be achieved by examination of the lungs. Adult V. alces can be isolated and identified, and the pathological changes caused by this parasite, most notably a localized bronchopneumonia with characteristic, well defined and greish brood nodules containing large numbers of eggs and larvae, can easily be distinguished from the lesions caused by $E$. cervi. This emphasises the importance of not only examining the faeces but also the lungs if a reliable diagnosis is to be obtained.

Red deer are mainly found on the west coast of Norway, from Rogaland in the south to Nord-Trondelag in the north, while reindeer inhabit the central mountain areas. In general, there are few red deer in areas with moose, except for S $\varnothing$ r- and NordTrøndelag where mixed populations are common. Nor is there much contact between reindeer and moose populations, except for some forest areas bordering the central Norwegian mountain areas. Red deer and reindeer are both known to harbour elaphostrongylid infection (Bakken \& Sparboe 1973, Helle 1980). Moreover, in the municipality with the highest prevalence of E. cervi infection in moose, Orkdal (52\%) in Sør-Trøndelag, red deer have been shown to have very high prevalence of infection with E. cervi (Ottestad 1983). Other municipalities populated by red deer also showed a high prevalence of E. cervi infection in moose, e.g. Namsos (48\%) and Verdal $(47 \%)$ in Nord-Trøndelag and Midtre-Gauldal $(45 \%)$ in Sør-Trøndelag. In contrast there was a low prevalence of E. cervi infection in moose in municipalities where reindeer occurred.

Although no significant difference in the prevalence of $\mathbf{E}$. cervi infection in moose was demonstrated between areas with mixed cervid populations and areas with moose only, the highest prevalence in moose was found in areas with populations of both moose and red deer, the latter known to harbour E.cervi. This may indicate that $E$. cervi found in moose and red deer belong to the same species, and that cross-infection may occur. Studies involving experimental cross-infection between moose, red deer and reindeer will be needed in order to elucidate these questions.

The lack of correlation between the population density of moose and the prevalence of $\mathbf{E}$. cervi infection demonstrated in the present study is noteworthy. However, because the life cycle of $\mathbf{E}$. cervi involves a snail intermediate host, a simple relation- 
ship between population density of moose and prevalence can not be expected when all municipalities are considered collectively. The distribution of the snail intermediate host probably differs greatly both within and between the various municipalities, depending on ecological conditions. Moose density may also vary considerably within a municipality. However, the variation in prevalence between municipalities and the lack of correlation between population density and prevalence both indicate that the epidemiology of elaphostrongylid infections in moose is complex.

\section{ACKNOWLEDGEMENT}

This study was financially supported by the Norwegian Agricultural Research Council and by the Directorate for Nature Management. I thank Professor O. Helle and Dr. G. Holt for essential help and guidance, Dr. B. Gjerde for linguistic advice and P. O. Bjønnes, A. Husdal and B. Øien for technical assistance. Thanks are also due to county wildlife managers, local wildlife authorities and hunters throughout Southern Norway, whose assistance in collecting the material made this study possible.

\section{REFERENCES}

Bakken, G. \& O. Sparboe: Elaphostrongylose has rein (Elaphostrongylosis in reindeer). Nord. Vet.-Med. 1973, 25, 203-210.

Cameron, T. V. M.: On two new species of nematodes from Scottish red deer. J. Helminthol. 1931, 9, 213-216.

Demidova, N. V.\& M. I. Naumytsjeva: A new nematode Varestrongylus alces sp. nov. in moose (in Russian). Moskovskij PushnoMekhovoj Institut. Trudy. 1953, 4, 303-306.

Gaudernack, G., O. Halvorsen, A. Skorping \& K. A. Stokkan: Humoral immunity and output of first-stage larvae of Elaphostrongylus rangiferi (Nematoda) in rendieer, Rangifer tarandus. J. Helminthol. 1984, 58, 13-18.

Halvorsen, $O . \& A$. Skorping: The influence of temperature on growth and development of the nematode Elaphostrongylus rangiferi in the gastropods Arianta arbostorum and Euconulus fulvus. Oikos 1982, 38, 285-290.

Halvorsen, O. \& K. Wissler: Elaphostrongylus sp. (Nematoda, Protostrongylidea) and other helminths in faeces of moose (Alces alces L) in North-Norway. Fauna norw. 1983, 4, 37-40.

Helle, O.: Elaphostrongylus cervi Cameron, 1931 hos hjort (Cervus elaphus) i Norge. (Elaphostrongylus cervi in red deer in Norway). Norsk Vet.-T. 1980, 92, 677-678.

Holt, G.: Påvisning av elaphostrongylose hos elg i Sør-Norge gir grunn til en viss engstelse. (Demonstration of elaphostrongylosis in moose in South-Norway gives reason for some anxiety). Jakt, fiske og friluftsliv $1982,9,33-34$. 
Kutzer, E. \& H. Prosl: Zur Kenntnis von Elaphostrongylus cervi Cameron, 1931. I. Morphologie und Diagnose. (The knowledge of Elaphostrongylus cervi Cameron, 1931. I. Morphology and Diagnosis). Wien. tierärztl. Mschr. 1975, 62, 258-266.

Lankester, M. V.: Neurological disorders in moose caused by Elaphostrongylus cervi Cameron, 1931 from caribou. Proc. 31th Ann. North American Moose Conference and Workshop. Jasper, Alberta 1977, p. 177-190.

Lankester, M. V. \& T. H. Northcott: Elaphostrongylus cervi Cameron, 1931 (Nematoda: Metastrongyloidea) in caribou (Rangifer tarandus caribou) of New Foundland. Canad. J. Zool. 1979, 57, $1384-1392$.

Lubimow, M. P.: New worm diseases of the brain of deer with unossified antlers (in Russian). Sbornik nauchoissledovatel'skikh rabot. Laboratory pantovogo olenvodstva Ministerstva sovkhozov SSSR 1945, 1, 225-232.

Mitskevich, W. J.: Studies on the life cycle of the nematode Elaphostrongylus ranigefri sp. nov. in reindeer. Dokl. Akad.nauk. SSSR 1958, 118, 253-255.

Mitskevich, W. J.: The development cycle of Elaphostrongylus rangiferi Miz. 1958 (in Russian). Sbornik, „Parazity sel skokhoziastv. Zhivotnykh Kazakhstana” 1964, 3, 59-60.

Munroe, R. \& A. R. Hunter: Histopatological findings in the lungs of Scottish red and roe deer. Vet. Rec. 1983, 112, 194-197.

Nilsson, $O$.: The interrelationships of endo-parasites in wild cervids (Capreolus capreolus L. and Alces alces L.) and domestic ruminants in Sweden. Acta vet. scand. 1971, 12, 36-68.

Ottestad, A. K.: Forekomst av Elaphostrongylus cervi i en populasjon av hjert (Cervus elaphus). (Occurrence of E. cervi in a population of red deer). University of Troms $\phi$, Troms $\phi 1983,64 \mathrm{p}$.

Prosl, H. \& E. Kutzer: Zur Biologie und Bekämpfung von Elaphostrongylus cervi. (The biology and eradication of Elaphostrongylus cervi). Z. Jagdwiss. 1980, 26, 198-207.

Pryadko, E. I.: Helminths of cervids. Alma Ata, USSR. Izdatel'stvo Nauka Kazakhskoi 1976, p. $1-224$.

Pryadko, E. I. \& S. N. Boev: Systematics, phylogeny and evolution of Elaphostrongylinea - nematodes of deer. Izv. Akad. Nauk. Kaz. SSSR. Ser. Zool. 1971, 3, 74-85.

Reimers, E.: Storvilt (Big game animals). Norges jeger og fiskerforbund, Landbruksforlaget 1981, p. 109-139.

Reimers, E. \& Ø. Nordby: Relationship between age and tooth cementum layers in Norwegian reindeer. J. Wild. Manage. 1968, 32, $322-325$.

Wissler, K. \& O. Halvorsen: Infection of reindeer with Elaphostrongylus rangiferi (Nematoda: Metastrongyloidea) in relation to age and season. Nor. J. Zool. 1976, 24, 462-463.

Øien, A.: Ed. Central Bureau of Statistics of Norway. Hunting Statistics 1981. Oslo 1982.

Øien, A.: Ed. Central Bureau of Statistics of Norway. Hunting Statistics 1983. Oslo 1984. 


\section{SAMMENDRAG \\ Prevalensen av Elaphostrongylus cervi infeksjon hos elg (Alces alces) i Sør-Norge.}

Prevalensen av Elaphostrongylus cervi infeksjon hos elg ble unders $\phi$ kt hos dyr skutt under jakt h $\phi$ sten 1983 i 47 forskjellige kommuner i S $\varnothing$ r-Norge. E. cervi ble påvist hos $35 \%$ av 1.982 unders $\varnothing$ kte dyr og ser ut til å forekomme endemisk i elgpopulasjonen. Grunnlaget for diagnosen i denne undersøkelsen er påvisning av egg og førstestadiums larver $\left(\mathrm{L}_{1}\right)$ av $\mathrm{E}$. cervi og histopatologiske forandringer forårsaket av disse $\mathrm{i}$ lungene og påvisning av $\mathrm{L}_{1} \mathrm{i}$ avføringsprøver. Prevalensen varierte sterkt fra kommune til kommune. Det ble ikke funnet noen sammenheng mellom prevalens og populasjonstetthet av elg. Høyest prevalens hos elg ble funnet i kommuner der det er hjort som en vet er infisert med E. cervi. Hanndyr hadde høyere prevalens enn hunndyr, uansett alder, og åringer hadde høyere prevalens enn kalver og eldre dyr uansett kjøn. E. cervi ble ikke påvist hos elg som var $5 \frac{1}{2}$ år eller eldre. Slaktevekten var signifikant lavere hos infiserte enn hos ikke infiserte dyr i aldersgruppen over 11/2 år. Den geografiske utbredelsen og den hфye prevalensen av E. cervi infeksjon hos elg indikerer at dette ikke er et nyetablert vert/parasitt system. På tross av den påviste negative effekten av denne infeksjonen på dyras slakevekt viser unders $\emptyset$ kelsen at parasiten antagelig bare er moderat patogen hos elg.

(Received June 9, 1986).

Reprints may be requested from: G. Stuve, the National Veterinary Institute, P. O. Box 8156, Dep., N-0033 Oslo 1, Norway. 